\title{
ANALISIS FINANSIAL USAHA PERIKANAN TANGKAP DI TELUK AMBON LUAR SEBAGAI UPAYA PENGELOLAAN PERIKANAN BERKELANJUTAN
}

\author{
(Financial Analysis of Capture Fisheries Business in Outer Ambon Bay \\ as a Sustainable Fisheries Management Effort)
}

\author{
Dahlan Amura $^{1^{*}}$ dan Pirhel $^{2}$ \\ 1) Progam Studi Pengolahan Hasil Perikanan Politeknik Kelautan dan Perikanan Maluku \\ 2) Prorgam Studi Budidaya Ikan Politeknik Kelautan dan Perikanan Maluku \\ raniamura09@gmail.com,pirhelhel@yahoo.com \\ Corresponding author*
}

\begin{abstract}
ABSTRAK: Perairan Teluk Ambon memiliki potensi sumberdaya perikanan dan kelautan yang menjanjikan dan dapat dimanfaatkan untuk kesejahteraan masyarakat. Wilayah perairan ini dapat dijadikan ladang bisnis bagi masyarakat maupun pengusaha untuk mendapatkan keuntungan dengan memanfaatkan sumberdaya ikan. Penelitian ini bertujuan untuk menganalisis kelayakan finansial usaha penangkapan ikan yang menggunakan alat tangkap bagan, bubu, jaring dasar, jaring permukaan, pancing tangan, pancing tonda, pancing rawai, dan pukat cincin di Perairan Teluk Ambon Luar (TAL). Penelitian ini dilakukan pada September 2019-Februari 2020 di perairan Teluk Ambon Luar. Penelitian menggunakan metode survei dengan teknik wawancara langsung terhadap responden secara acak berjumlah 15-16 orang nelayan. Databyang diperoleh akan dianalisis kelayakan usaha meliputi Gross Benefit/Cost Ratio, Net Benefit/Cost Ratio, Profitability Ratio dan Net Present Value. Metode skoring digunakan untuk menganalisis hasil analisis financial mengenai kriteria investasi dari masing-masing usaha perikanan tangkap di TAL. Hasil penelitian menunjukan, berdasarkan analisa kalayakan finansial untuk semua jenis alat tangkap dikategorikan menguntungkan dan layak. Usaha perikanan tangkap yang menguntungkan dan terbaik di wilayah TAL adalah dari jenis usaha perikanan tangkap yang menggunakan bubu dengan skor 3,55, diikuti oleh pancing rawai dengan nilai skor 2,70 , serta pancing tonda dengan nilai skor 2,10 . Tingkat pemanfaatan masyarakat nelayan TAL terhadap kelimpahan stok sumberdaya ikan pelagis kecil dan demersal di TAL juga relatif rendah masing-masing sekitar $47 \%$ dan $48 \%$.
\end{abstract}

Kata Kunci: Analisis finansial, kelayakan usaha, perikanan tangkap, alat tangkap, Teluk Ambon Luar

ABSTRACT: Waters of Ambon Bay has the potential of promising fisheries and marine resources and can be utilized for the welfare of the community. The waters area can be used as a business field for people and entrepreneurs to get profit by utilizing fish resources. This study aims to analyze the financial feasibility of fishing using lift net, trap, bottom gillnet, surface gillnet, hand line, troll line, long line, and purse seine in the waters of Outer Ambon Bay. This research was conducted in September 2019-February 2020 in the waters of Outer Ambon Bay. The study used a survey method with direct interview techniques to respondents randomly of 15-16 fishermen. The data obtained will be analyzed for business feasibility including Gross Benefit/Cost Ratio, Net Benefit/Cost Ratio, Profitability Ratio and Net Present Value. The scoring method is used to analyze the results of financial analysis regarding the investment criteria of each capture fishery business in Outer Ambon Bay. The 
results showed, based on financial feasibility analysis, all types of fishing gear were categorized as profitable and feasible. The best profitable and best capture fisheries business in the Outer Ambon Bay area are the types of capture fishery business that uses traps with a score of 3,55, followed by long line fishing with a score of 2,70, and trolling lines with a score of 2,10. The utilizing rate of Outer Ambon Bay fishermen communities to the abundance of small pelagic fish and demersal fish resource stock is also relatively low of $47 \%$ and $48 \%$, respectively.

Keywords: Financial analysis, business feasibility, capture fisheries, fishing gear, Outer Ambon Bay

\section{PENDAHULUAN}

Sektor perikanan merupakan sektor yang penting dan strategis dalam mendukung pembangunan nasional (Triarso, 2012), salah satunya yaitu perikanan tangkap. Perikanan tangkap memiliki peran penting dan strategis di Indonesia, setidaknya dapat dilihat dari tiga peran, yaitu sumber pertumbuhan ekonomi, sumber pangan khususnya protein hewani, dan penyedia lapangan kerja (Rizal, dkk., 2018; Sanger, $d k k .$, 2019). Menurut Kusdiantoro, $d k k$. (2019), keberlanjutan perikanan tangkap di Indonesia bukan hanya dapat memberikan mafaat secara ekonomi, namun juga ditinjau dari aspek sosial, kelembagaan dan yang terpenting ekologi. Lebih lanjut dikatakan bahwa tujuan pembangunan berkelanjutan pada sektor perikanan tangkap secara ekonomis mampu menghasilkan produk ikan yang berkelanjutan serta meningkatkan kesejahteraan pelaku usaha perikanan dalam hal ini nelayan, serta memberikan sumbangan devisa bagi negara. Secara ekologi, tidak terjadi eksploitasi berlebihan terhadap ketersediaan sumberdaya ikan di alam, sehingga perlu diperluas kawasan konservasi yang bertujuan untuk perlindungan sumberdaya. Secara sosial diharapkan agar kondisi sumberdaya perikanan yang open acces ini tidak menimbulkan konflik antar pelaku yang umumnya nelayan tradisional. Secara kelembagaan, perlu dibentuk keompok usaha bersama (KUB).

Perairan Kota Ambon mempunyai sumberdaya alam yang didominasi dari sektor kelautan dan perikanan, sehingga wilayah pesisir dan laut merupakan salah satu wilayah potensial dalam mendukung sektor riil. Dalam rencana pengembangan di sektor perikanan di Kota Ambon difokuskan pada lima wilayah pesisir, yaitu: Wilayah Teluk Ambon Dalam (TAD), Teluk Ambon Luar (TAL), Teluk Baguala (TB), Pesisir Selatan Kota Ambon (PSKA) dan Kepulauan Lucipara, masingmasing memiliki panjang garis pantai: 14,003 $\mathrm{km} ; 44,48 \mathrm{~km} ; 12,68 \mathrm{~km} ; 30,12 \mathrm{~km}$ dan 19,68 $\mathrm{km}$. Keseluruhan wilayah tersebut memiliki potensi perikanan laut yang besar, yaitu terdiri dari ikan-ikan pelagis besar, pelagis kecil dan ikan-ikan demersal. Ikan pelagis besar yang umumnya terdiri dari jenis-jenis ikan tuna (Thunnus sp) dan Cakalang (Katsuwonus pelamis) dengan tingkat pemanfaatan sekitar $41 \%$. Ikan-ikan pelagis besar ini umumnya terdapat di wilayah selatan Kota Ambon, sedangkan ikan-ikan pelagis kecil terdapat di seluruh wilayah Teluk Ambon Dalam (TAD), Teluk Ambon Luar (TAL), Teluk Baguala (TB), Selatan Kota Ambon (SKA) dan Kepulauan Lucipara. Tingkat pemanfaatannya secara keseluruhan masih rendah, yaitu sekitar 0,28\% dari potensi lestari. Potensi lestari ikan pelagis kecil di masing-masing wilayah TAD, TAL, TB, SKA dan Kepulauan Lucipara adalah: 29,3; 196; 12,1; 498 dan 85 ton/bulan. Sedangkan untuk ikan-ikan demersal tingkat pemanfaatannya juga masih terbatas pada wilayah TAD, TAL, TB dan SKA, masingmasing masih mencapai: 9,8; 11,5; 4,5 dan 10,1 ton/bulan. Pemanfaatan tersebut masih jauh dari potensi ikan demersal yang dimiliki di wilayah tersebut yang masing-masing diketahui sebesar 23,7 ton/bulan untuk TAL; 6,4 ton/bulan untuk TB dan 90 ton/bulan untuk SKA, sedangkan untuk wilayah TAD dan Kepulauan Lucipara potensi ikan demersal belum dapat 
diprediksikan (DKP, 2003). Berdasarkan hasil penelitian Noija, $d k k$. (2014), ditemukan 22 jenis ikan demersal di perairan Pulau Ambon dengan lima jenis yang dominan tertangkap yaitu lencam (Lethrinus sp), kurisi (Etelis spp), kerapu (Ephinephelus sp), kakap merah (Lutjanus spp), ikan bobara (Caranx sp). Selanjutnya dikatakan berdasarkan hasil analisa diperoleh potensi lestari (MSY) ikan lencam 1575 ton dengan tingkat pemanfaatan $19.19 \%$, ikan kurisi 67 ton dengan tingkat pemanfaatan $59.63 \%$, ikan kerapu 572.02 ton dengan tingkat pemanfaatan $31.27 \%$, kakap merah 146.83 ton dengan tingkat pemanfaatan $47.47 \%$, dan ikan bubara 270.60 ton dengan tingkat pemanfaatan $26.96 \%$.

Perairan Teluk Ambon Luar memiliki potensi sumberdaya pesisir dan laut yang cukup menjanjikan dan dapat dimanfaatkan untuk kemakmuran masyarakat. Total produksi perikanan di kawasan perairan Teluk Ambon luar sebesar 4.253,63 ton per tahun (DKP, 2008). Potensi lestari ikan pelagis kecil sebesar 196 ton/bln dengan tinggkat pemanfaatan sebesar 158 ton/bulan, sedangkan untuk ikan demersal memiliki nilai potensi lestari 23,7 ton/bln dengan tingkat pemanfaatan sebesar 11,5 ton/bln. Perairan Teluk Ambon Luar banyak ditumbuhi berbagai terumbu karang yang merupakan merupakan habitat berbagai jenis biota perairan. Berdasarkan hasil penelitian kondisi karang di perairan Teluk Ambon diperoleh rata-rata karang hidup sebesar $31,43 \%$ di tahun 2015 dan termasuk kategori sedang (Indrabudi\&Alik, 2017). Jenis dan jumlah unit alat tangkap ikan pada wilayah TAL ini cukup banyak jika dibandingkan daerah lainnya di kota Ambon, yaitu terdapat 13 jenis alat tangkap (447 unit) dan merupakan wilayah kedua yang memiliki jumlah unit terbanyak setelah SKA dengan 13 jenis (615 unit) alat tangkap ikan (DKP, 2003).

Jika ditinjau dari segi potensi sumberdaya alam yang berasal dari perairan laut seperti yang telah diuraikan di atas, jelas menunjukan bahwa wilayah perairan Kota Ambon dalam hal ini Teluk Ambon merupakan wilayah yang cukup menjanjikan dan merupakan ladang bisnis bagi seluruh pengusaha-pengusaha perikanan di luar kota Ambon. Oleh karena itu, untuk membuka suatu usaha bisnis khususnya di bidang perikanan perlu memperhatikan faktor-faktor financial. Pentingnya analisis finansial dalam suatu usaha menjamun keberlanjutan usaha serta sumberdaya yang dimanfaatkan. Analisis kelayakan usaha perikanan tangkap ikan pelagis besar bertujuan untuk menilai sejauh mana manfaat secara finansial yang diterima melalui usaha tersebut. Tujuan penelitian ini adalah menganalisis kelayakan finansial usaha penangkapan ikan yang menggunakan alat tangkap meliputi bagan, bubu, jaring dasar, jaring permukaan, pancing tangan, pancing tonda, pancing rawai, dan pukat cincin di Perairan Teluk Ambon Luar (TAL).

\section{METODE PENELITIAN}

Penelitian ini dilakukan pada September 2019 hingga Februari 2020 di perairan Teluk Ambon Luar. Penelitian menggunakan metode survei yaitu dengan menggunakan teknik wawancara langsung terhadap responden secara acak berjumlah 15-16 orang nelayan. Sehubungan dengan jumlah unit dari masingmasing alat tangkap yang ada di Teluk Ambon Luar tidak sama, yang jumlahnya sangat bervariasi (pancing tangan 245 unit, pancing tonda 65 unit, pancing rawai 1 unit, bubu 13 unit, jaring permukaan 13 unit, jaring dasar 59 unit, jaring tramelnet 1 unit, bagan 2 unit dan pukat cincin 3 unit).

Data yang diperoleh dianalisis menggunakan analisis finansial dengan variabel-variabel yang akan dianalisis adalah biaya, penerimaan dan pendapatan dalam nilai sekarang (net present value) dari setiap usaha penangkapan yang menggunakan alat tangkap yang telah disebutkan sebelumnya. Data dari setiap jenis alat tangkap yang jumlahnya lebih dari satu unit akan terlebih dahulu dirataratakan. Selanjutnya setiap jenis usaha ditentukan nilai (Kadariah, 1999): Gross Benefit/Cost Ratio, Net Benefit/Cost Ratio, Profitability Ratio dan Net Present Value.

a. Perhitungan Gross Benefit Cost Ratio (Gross B/C) menurut Ibrahim (2003) adalah sebagai berikut: 


$$
\operatorname{Gross} B / C=\frac{\sum_{t=0}^{n} P V(+)}{\sum_{t=0}^{n} P V(-)}
$$

Ket:

Gross B/C = Gross Benefit Cost Ratio

$\mathrm{PV}(+) \quad=$ Present value $(+)$

$\mathrm{PV}(-) \quad=$ Present value $(-)$

b. Perhitungan Net Benefit Cost Ratio (Net B/C) menurut Ibrahim (2003) adalah sebagai berikut:

$$
\text { Net } B / C=\frac{\sum_{t=0}^{n} \frac{B t-C t}{(1+i) t}}{\sum_{t=0}^{n} \frac{B t-C t}{(1-i) t}}
$$

\section{Ket:}

$\mathrm{Bt}=$ Benefit total pada tahun ke $\mathrm{t}(\mathrm{Rp})$

$\mathrm{Ct}=$ Biaya total pada tahun ke $\mathrm{t}(\mathrm{Rp})$

$\mathrm{i} \quad=$ Tingkat bunga yang berlaku

$\mathrm{t}=$ Waktu

$\mathrm{n} \quad=$ Umur ekonomis proyek (tahun)

c. Probability Ratio (PR) dihitung dengan menggunakan rumus (Ibrahim, 2003) sebagai berikut:

$$
P R=\frac{P V \text { Net Benefit }}{P V \text { Investasi }}
$$

d. Perhitungan Net Present Value (NPV) menggunakan rumus (Gray, dkk., 2002) adalah sebagai berikut:

$$
N P V=\sum_{t=0}^{n}(\text { Net Benefit })(D F)
$$

Ket:

NPV $=$ Net present value

$\mathrm{DF}=$ Tingkat suku bunga yang berlaku $(\%)$

Menurut Kadariah (1999), untuk menetukan usaha yang menguntungkan maka digunakan kriteria sebagai berikut:

- Bila $B / C$ ratio < 1 berarti suatu proyek/usaha tidak menguntungkan

- Bila $B / C$ ratio $\geq 1$ berarti suatu proyek/usaha menguntungkan

- Profitability ratio $\geq 1$ berarti suatu proyek/usaha menguntungkan

- NPV > 0 berarti suatu proyek/usaha menguntungkan

Analis skoring digunakan untuk menganalisis hasil analisis financial mengenai kriteria investasi, yaitu nilai-nilai dari Gross B/C, Net B/C, Profitability ratio dan Net Present Value dari masing-masing usaha perikanan tangkap yang ada di TAL.

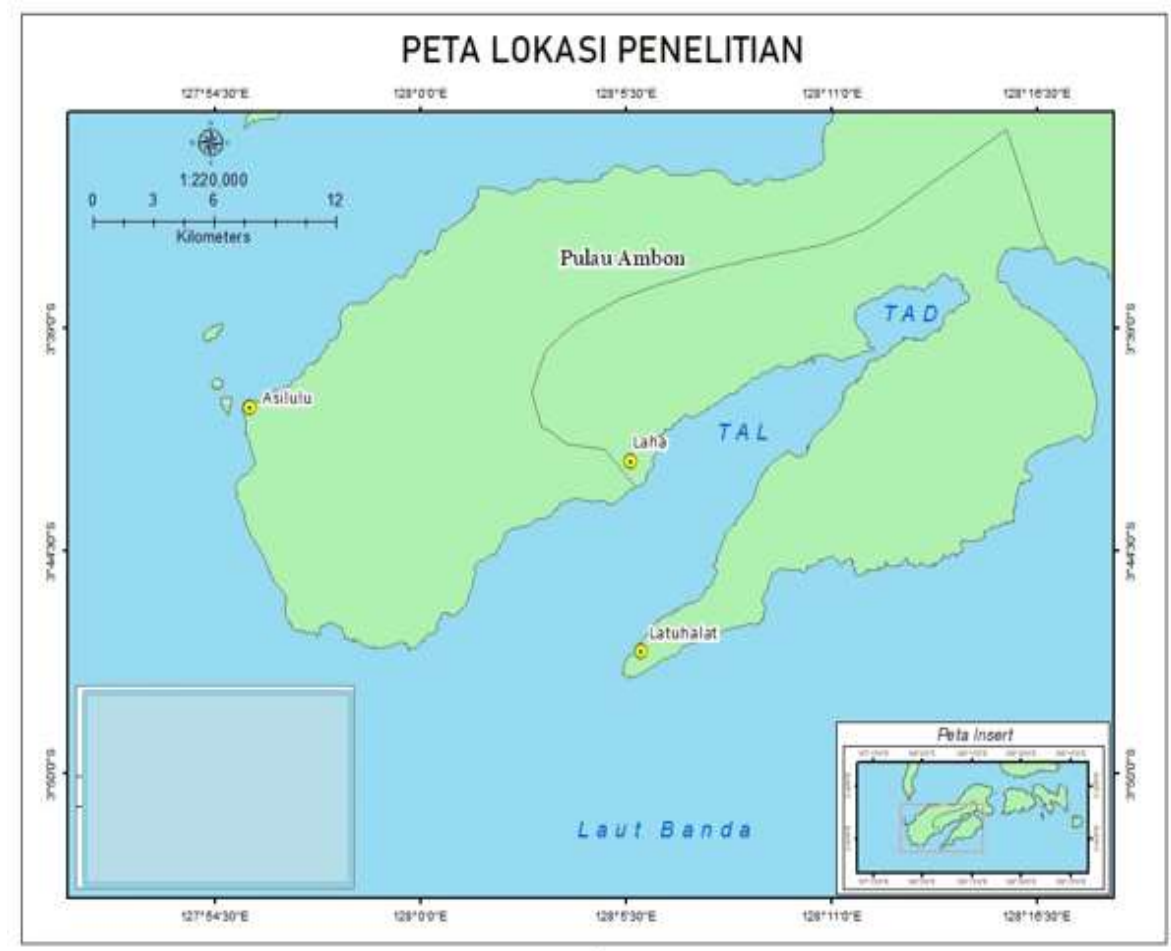

Gambar 1. Lokasi Penelitian 


\section{HASIL DAN PEMBAHASAN}

\section{A. Usaha Perikanan dengan Alat Tangkap Bagan}

Usaha perikanan dengan alat tangkap bagan yang dioperasikan di TAL berasal dari Desa Wayame yang hanya 1 (satu) unit saja. Satu unit alat tangkap bagan memiliki usia ekonomis mencapai 14 tahun (data primer hasil wawancara dengan nelayan). Berdasarkan analisis financial usaha ini memiliki benefit kotor antara Rp.30.000.000Rp.75.000.000/tahun. Jika dihitung dengan tingkat bunga sekitar $16 \%$, maka diperoleh nilai present value gross benefit sekitar Rp.5.000.000-Rp.44.000.000/tahun (Tabel 1). Nilai Gross $\mathrm{B} / \mathrm{C}=1,52 ;$ Net $\mathrm{B} / \mathrm{C}=2,72$; Profiability ratio $=2,34$ dan Net Present Value $=100.784 .670$. Beberapa penelitian membuktikan, hasil analisa finansial usaha perikanan bagan sangat layak untuk dilakukan dan dikembangkan (Farhaby, 2019; Dirja\&Abdurahman, 2019).

Tabel 1. Cost dan Benefit usaha dengan alat tangkap bagan

\begin{tabular}{ccccc}
\hline Tahun & $\begin{array}{c}\text { Total Cost } \\
(\mathrm{C})\end{array}$ & $\begin{array}{c}\text { Benefit }(\mathrm{B}) \\
(000)\end{array}$ & $\begin{array}{c}\text { PV. Gross } \\
\text { C } \\
(000)\end{array}$ & $\begin{array}{c}\text { PV. Gross B } \\
(000)\end{array}$ \\
\hline I & 90.000 & 30.000 & $77.586,21$ & $25.862,07$ \\
II & 18.130 & 60.000 & $13.473,54$ & $44.589,77$ \\
III & 18.100 & 54.000 & $11.595,90$ & $34.595,51$ \\
IV & 18.150 & 78.000 & $10.024,08$ & $43.078,71$ \\
V & 21.580 & 42.000 & $10.274,52$ & $19.996,75$ \\
VI & 18.830 & 57.000 & $7.728,63$ & $23.395,21$ \\
VII & 18.200 & 66.000 & $6.439,70$ & $23.352,75$ \\
VIII & 18.100 & 48.000 & $5.520,96$ & $14.641,22$ \\
IX & 25.150 & 72.000 & $6.613,27$ & $18.932,61$ \\
X & 48.225 & 33.000 & $10.931,82$ & $7.480,56$ \\
XI & 49.250 & 69.000 & $9.624,28$ & $13.483,77$ \\
XII & 48.150 & 75.000 & $8.111,49$ & $12.634,71$ \\
XIII & 48.250 & 39.000 & $7.007,91$ & $5.663,84$ \\
XIV & 57.150 & 41.250 & $7.154,91$ & $5.164,31$ \\
\hline Sumber $:$ Data yang diolah & & & \\
& & & &
\end{tabular}

\section{B. Usaha Perikanan dengan Alat Tangkap Bubu}

Usaha perikanan dengan alat tangkap bubu yang dioperasikan di TAL berasal berbagai desa, yaitu Desa Laha, Alang, Hative besar, Wayame, Lilyboy dan Desa Urimessing, berjumlah 7 (tujuh) unit. Satu unit alat tangkap bubu memiliki usia ekonomis sekitar 5 tahun saja. Berdasarkan analisis financial usaha ini memiliki benefit kotor antara Rp.300.000Rp.2.471.000/tahun, jika dengan tingkat bunga sekitar $16 \%$, maka diperoleh present value gross benefit sekitar Rp.258.620Rp.1.336.410/tahun (Tabel 2). Nilai Gross $\mathrm{B} / \mathrm{C}=4,35$; Net $\mathrm{B} / \mathrm{C}=12,61 ; \quad$ Profiability ratio $=8,05$ dan Net Present Value=3.642.500. Berdasarkan data hasil penelitian, jenis alat tangkap dengan menggunakan bubu sangat menguntungkan dibandingkan dengan alat tangkap lainnya, karena berdasarkan perhitungan kriteria investasi diperoleh nilai skor tertinggi yaitu 3,55. Bubu merupakan alat tangkap yang berjenis perangkap yang bersifat pasif dan bersifat tradisional yang pada umumnya berbahan dasar bambu, rotan, kawat, besi, jaring dan kayu. Bubu merupakan alat tangkap yang selektif dan ramah lingkungan dalam penerapannya di dalam kegiatan usaha penangkapan ikan (Rizky, dkk., 2018).

Tabel 2. Cost dan benefit Usaha dengan Alat Tangkap Bubu

\begin{tabular}{ccccc}
\hline Tahun & $\begin{array}{c}\text { Total } \\
\text { Cost }(\mathrm{C}) \\
(000)\end{array}$ & $\begin{array}{c}\text { Benefit } \\
(\mathrm{B}) \\
(000)\end{array}$ & $\begin{array}{c}P V . \\
\text { Gross } \mathrm{C} \\
(000)\end{array}$ & $\begin{array}{c}\text { PV. Gross } \\
\text { B } \\
(000)\end{array}$ \\
\hline I & 664 & 300 & 572,41 & 258,62 \\
II & 107 & 1.157 & 79,52 & 859,84 \\
III & 142 & 2.086 & 90,97 & $1.336,41$ \\
IV & 275 & 1.986 & 151,88 & $1.096,85$ \\
V & 401 & 2.471 & 190,92 & $1.176,48$ \\
\hline \multicolumn{2}{l}{ Sumber : Data yang diolah } & & &
\end{tabular}

\section{Usaha Perikanan dengan Alat Tangkap Jaring Dasar}

Usaha perikanan dengan alat tangkap jaring dasar yang dioperasikan di TAL berasal dari berbagai desa, yaitu desa Laha, Hative Besar dan Latuhalat dengan jumlah 59 (lima puluh sembilan) unit. Satu unit alat tangkap jaring dasar memiliki usia ekonomis hanya sekitar 5 tahun. Berdasarkan analisis financial usaha ini memiliki benefit kotor antara Rp.2.500.000-4.735.000/tahun serta dengan tingkat bunga sekitar $16 \%$, maka diperoleh nilai present value gross benefit sekitar Rp.2.155.170-Rp.3.401.460/tahun (Tabel 3). Nilai Gross $\mathrm{B} / \mathrm{C}=1,24$; Net $\mathrm{B} / \mathrm{C}=2,53$; Profiability ratio $=1,92$ dan Net Present Value $=2.535 .720$. Hasil analisis menunjukan bahwa alat tangkap ini layak digunakan karena menunjukan kelayakan usaha dilihat dari hasil 
analisis nilai gross benefit dan present value gross benefit lebih besar dari 1. Hasil penelitian di Desa Pohuwato Timur, Teluk Tomini diperoleh total penerimaan untuk usaha nelayan jaring insang dasar yaitu mencapai Rp.93.312.000 (Syarif, $d k k .$, 2016).

Tabel 3. Cost dan Benefit usaha dengan alat tangkap jaring dasar

\begin{tabular}{|c|c|c|c|c|}
\hline Tahun & $\begin{array}{c}\text { Total } \\
\text { Cost (C) } \\
(000)\end{array}$ & $\begin{array}{c}\text { Benefit } \\
\text { (B) } \\
(000)\end{array}$ & $\begin{array}{c}P V . \\
\text { Gross } C \\
(000)\end{array}$ & $\begin{array}{c}\text { PV. Gross B } \\
(000)\end{array}$ \\
\hline I & 4.422 & 2.500 & $3.812,07$ & $2.155,17$ \\
\hline II & 2.537 & 4.577 & $1.885,40$ & $3.401,46$ \\
\hline III & 2.529 & 4.677 & $1.620,22$ & $2.966,36$ \\
\hline IV & 2.857 & 4.009 & $1.577,90$ & $2.214,14$ \\
\hline V & 3.340 & 4.735 & $1.590,22$ & $2.254,40$ \\
\hline
\end{tabular}

\section{Usaha Perikanan dengan Alat Tangkap Jaring Permukaan}

Usaha perikanan dengan alat tangkap jaring permukaan yang dioperasikan di TAL berasal dari berbagai desa, yaitu Desa Alang, Hative Besar, Amahusu, Latuhalat dan Urimessing dengan jumlah keseluruhannya sekitar 13 (tiga belas) unit. Satu unit alat tangkap jaring permukaan memiliki usia ekonomis hanya sekitar 5 tahun. Berdasarkan analisis financial usaha ini memiliki benefit kotor antara Rp.2.015.000-Rp. 3.577.000/tahun, serta dengan tingkat bunga sekitar $16 \%$, maka diperoleh nilai present value gross benefit sekitar Rp.1.703.060-Rp.2.132.130/tahun (Tabel 4). Nilai Gross $\mathrm{B} / \mathrm{C}=1,78$; Net $\mathrm{B} / \mathrm{C}=4,73$; Profiability ratio $=2,39$ dan Net Present Value $=3.995 .920$.

Tabel 4. Cost dan Benefit usaha dengan alat tangkap jaring permukaan

\begin{tabular}{ccccc}
\hline Tahun & $\begin{array}{c}\text { Total } \\
\text { Cost }(C) \\
(000)\end{array}$ & $\begin{array}{c}\text { Benefit } \\
(B) \\
(000)\end{array}$ & $\begin{array}{c}\text { PV. Gross } \\
\text { C (000) }\end{array}$ & $\begin{array}{c}\text { PV. Gross } \\
\text { B }(000)\end{array}$ \\
\hline I & 3.258 & 2.015 & $2.808,62$ & $1.737,07$ \\
II & 620 & 2.869 & 460,76 & $2.132,13$ \\
III & 1.058 & 2.831 & 677,82 & $1.813,70$ \\
IV & 978 & 3.092 & 540,14 & $1.707,68$ \\
V & 1.282 & 3.577 & 610,38 & $1.703,06$ \\
\hline \multicolumn{5}{l}{ Sumber: Data yang diolah } \\
\end{tabular}

\section{E. Usaha Perikanan dengan Alat Tangkap Pancing Tangan}

Alat tangkap pancing tangan merupakan alat tangkap sederhana dalam pengoperasiannya. Umumnya, alat tangkap pancing tangan digunakan oleh nelayan skala kecil (Shadiqin, $d k k .$, 2018). Usaha perikanan dengan alat tangkap pancing tangan yang dioperasikan di TAL berasal dari dua desa, yaitu Desa Laha dan Wayame dengan jumlah keseluruhannya 245 unit. Satu unit alat tangkap pancing tangan memiliki usia ekonomis sekitar 5 tahun saja. Berdasarkan analisis financial usaha ini memiliki benefit kotor antara Rp.4.000.000-Rp.23.171.000/tahun serta dengan tingkat bunga sekitar $16 \%$, maka diperoleh present value gross benefit sekitar Rp.3.448.280-Rp.14.439.140/tahun (Tabel 5). Nilai Gross $\mathrm{B} / \mathrm{C}=1,54$; Net $\mathrm{B} / \mathrm{C}=6,80$; Profiability ratio $=4,01$ dan Net Present Value $=17.193 .110$. Hasil penelitian Patawari (2018) menyatakan bahwa pendapatan nelayan pancing ulur di Desa Bongo Kabupaten Gorontalo sebesar Rp.27.012.297/tahun atau rata-rata $\mathrm{Rp} .2 .251 .000 / \mathrm{bulan}$.

Tabel 5. Cost dan Benefit usaha perikanan dengan alat tangkap pancing tangan

\begin{tabular}{ccccc}
\hline Tahun & $\begin{array}{c}\text { Total } \\
\text { Cost } \\
(C)\end{array}$ & $\begin{array}{c}\text { Benefit } \\
(B) \\
(000)\end{array}$ & $\begin{array}{c}P V . \\
\text { Gross } C \\
(000)\end{array}$ & $\begin{array}{c}P V . \\
\text { Gross } B \\
(000)\end{array}$ \\
& $(000)$ & & & \\
\hline I & 7.438 & 4.000 & $6.412,07$ & $3.448,28$ \\
II & 7.419 & 12.000 & $5.513,53$ & $8.917,95$ \\
III & 10.250 & 22.538 & $6.566,74$ & $14.439,14$ \\
IV & 12.422 & 20.342 & $8.860,56$ & $11.234,71$ \\
V & 13.707 & 23.171 & $6.526,08$ & $11.032,01$ \\
\multicolumn{5}{l}{ Sumber: Data yang diolah }
\end{tabular}

\section{F. Usaha Perikanan dengan Alat Tangkap Pancing Tonda}

Usaha perikanan dengan alat tangkap pancing tonda yang dioperasikan di TAL berasal dari berbagai desa, yaitu desa Hurimessing, Latuhalat dan Laha dengan jumlah keseluruhannya 65 unit. Satu unit alat tangkap pancing tonda memiliki usia ekonomis sekitar 5 tahun. Berdasarkan analisis financial usaha ini memiliki benefit kotor antara Rp.35.000.000-Rp.125.000.000/tahun serta 
dengan tingkat bunga sekitar 16\%, maka diperoleh present value gross benefit sekitar Rp.30.172.410-69.036.390/tahun (Tabel 6). Nilai Gross $\mathrm{B} / \mathrm{C}=1,47$; Net $\mathrm{B} / \mathrm{C}=6,61$; Profiability ratio $=5,13$ dan Net Present Value $=78.716 .190$. Penelitian Purwasih, $d k k$. (2016) menyatakan bahwa pendapatan kotor nelayan pada usaha penangkapan dengan pancing tonda sebesar Rp.31.766.500/trip, lebih kecil dibandingkan dengan pendapatan dari usaha penangkapan pukat cincin yaitu sebesar Rp.75.787.400/trip.

Tabel 6. Cost dan Benefit usaha perikanan dengan alat tangkap pancing tonda

\begin{tabular}{ccccc}
\hline Tahun & $\begin{array}{c}\text { Total } \\
\text { Cost }(C) \\
(000)\end{array}$ & $\begin{array}{c}\text { Benefit } \\
(B) \\
(000)\end{array}$ & $\begin{array}{c}P V . \\
\text { Gross } C \\
(000)\end{array}$ & $\begin{array}{c}P V . \\
\text { Gross B } \\
(000)\end{array}$ \\
\hline I & 51.279 & 35.000 & $44.206,03$ & $30.172,41$ \\
II & 51.980 & 65.000 & $38.629,61$ & $48.305,59$ \\
III & 48.042 & 100.000 & $30.778,48$ & $64.065,77$ \\
IV & 48.083 & 125.000 & $26.555,81$ & $69.036,39$ \\
V & 56.665 & 72.000 & $26.974,18$ & $34.280,14$ \\
\multicolumn{5}{l}{ Sumber: Data yang diolah }
\end{tabular}

\section{G. Usaha Perikanan dengan Alat Tangkap Pancing Rawai}

Pancing rawai merupakan alat tangkap yang lebh murah dan mudah dioperasikan dibandingkan alat tangkap lain. Alat tangkap ini dapat dioperasikan sepanjang tahun dan dapat dilakukan oleh perseorangan (Wijayanti, $d k k$., 2015). Usaha perikanan dengan alat tangkap pancing rawai yang dioperasikan di TAL hanya berasal dari desa Hative Besar dengan jumlah hanya 1 (satu) unit. Satu unit alat tangkap pancing rawai memiliki usia ekonomis hanya sekitar 10 tahun. Berdasarkan analisis financial usaha ini memiliki benefit kotor antara Rp.500.000-1.500.000/tahun serta dengan tingkat bunga sekitar 16\%, maka diperoleh present value gross benefit sekitar Rp.276.150862.070/tahun (Tabel 7). Nilai Gross B/C=2,17; Net $\mathrm{B} / \mathrm{C}=13,37$; profiability ratio $=4,91$ dan net present value $=3.007 .950$.
Tabel 7. Cost dan Benefit usaha dengan alat tangkap pancing rawai

\begin{tabular}{ccccc}
\hline Tahun & $\begin{array}{c}\text { Total } \\
\text { Cost }(C) \\
(000)\end{array}$ & $\begin{array}{c}\text { Benefit } \\
(B) \\
(000)\end{array}$ & $\begin{array}{c}P V . \\
\text { Gross } C \\
(000)\end{array}$ & $\begin{array}{c}P V . \\
\text { Gross } B \\
(000)\end{array}$ \\
\hline I & 1.250 & 1.000 & $1.077,59$ & 862,07 \\
II & 350 & 1.000 & 260,11 & 743,16 \\
III & 650 & 1.000 & 416,43 & 640,66 \\
IV & 550 & 500 & 303,76 & 276,15 \\
V & 250 & 1.500 & 119,03 & 714,17 \\
VI & 250 & 1.500 & 102,61 & 615,66 \\
VII & 250 & 1.500 & 88,46 & 530,74 \\
VIII & 250 & 1.500 & 76,26 & 457,54 \\
IX & 250 & 1.500 & 65,74 & 394,43 \\
X & 250 & 1.500 & 56,67 & 340,03 \\
\hline Sumber : Data yang diolah & & &
\end{tabular}

\section{H. Usaha Perikanan dengan Alat Tangkap Pukat Cincin (Purse Seine)}

Alat tangkap purse seine merupakan alat tangkap yang efektif untuk menangkap ikanikan pelagis kecil di permukaan perairan (Tamarol\&Sarapil, 2017). Usaha perikanan dengan alat tangkap pukat cincin yang dioperasikan di TAL berasal dari Desa Latuhalat dan Urimessing dengan jumlah 3 (tiga) unit. Satu unit alat tangkap pukat cincin memiliki usia ekonomis mencapai 13 tahun. Berdasarkan analisis financial usaha ini memiliki benefit kotor antara Rp.8.483.000Rp.50.001.000/tahun serta dengan tingkat bunga sekitar $16 \%$, maka diperoleh present value gross benefit sekitar Rp.2.717.190Rp20.734.660/tahun (Tabel 8). Nilai Gross $\mathrm{B} / \mathrm{C}=1,16 ; \quad$ Net $\mathrm{B} / \mathrm{C}=1,32 ; \quad$ Profiability ratio $=1,21$ dan net present value $=15.536 .030$. Hasil penleitian Rahabeat, dkk. (2019) di Dusun Seri, Kota Ambon diperoleh rata-rata keuntungan tiap kapal yang menggunakan pukat cincin sebesar Rp.46.418.527/tahun. Selanjutnya dikatakan bahwa investasi pukat cincin di Dusun Seri layak untuk dikembangkan karena memiliki nilai NPV yang positif, net B/C $>1$ dan nilai IRR lebih besar dari social discount rate. 
Tabel 8. Cost dan Benefit usaha dengan alat tangkap pukat cincin

\begin{tabular}{ccccc}
\hline Tahun & $\begin{array}{c}\text { Total } \\
\text { Cost }(C)\end{array}$ & $\begin{array}{c}\text { Benefit } \\
(B)\end{array}$ & $\begin{array}{c}P V . \\
\text { Gross } C\end{array}$ & $\begin{array}{c}P V . \\
\text { Gross } B\end{array}$ \\
& $(000)$ & $(000)$ & $(000)$ & $(000)$ \\
\hline I & 63.400 & 8.483 & $54.655,17$ & $7.312,93$ \\
II & 4.500 & 20.465 & $3.344,23$ & $15.208,83$ \\
III & 20.950 & 17.976 & $13.421,78$ & $11.516,46$ \\
IV & 15.450 & 37.543 & $8.532,90$ & $20.734,66$ \\
V & 3.450 & 22.965 & $1.642,59$ & $10.933,94$ \\
VI & 10.450 & 17.143 & $4.289,12$ & $7.036,21$ \\
VII & 8.600 & 14.010 & $3.042,93$ & $4.957,15$ \\
VIII & 7.700 & 50.001 & $2.348,70$ & $15.251,58$ \\
IX & 8.300 & 19.471 & $2.182,51$ & $5.119,96$ \\
X & 9.800 & 35.071 & $2.221,50$ & $7.950,02$ \\
XI & 9.060 & 16.076 & $1.770,48$ & $3.141,52$ \\
XII & 7.650 & 20.431 & $1.288,74$ & $3.441,86$ \\
XIII & 7.200 & 18.710 & $1.045,63$ & $2.717,19$ \\
\hline Sumber: Data yang diolah & & &
\end{tabular}

\section{Nilai Gross B/C}

Net Benefit Cost Ratio digunakan untuk mengetahui besarnya benefit berapa kali besar biaya dan investasi untuk memperoleh manfaat (Gittinger, 2008). Nilai Gross B/C (Gross Benefit Cost Ratio) dari seluruh alat tangkap yang diteliti menunjukkan nilainya diatas 1 (Gross B/C > 1), dengan variasi nilai berkisar antara 1,16 hingga 4,35. Alat tangkap yang memiliki nilai terendah adalah pukat cincin, yaitu, sedangkan nilai yang tertinggi dicapai oleh alat tangkap bubu kemudian diikuti oleh pancing rawai $(2,17)$ dan jaring permukaan $(1,78)$ (Gambar 2).

\section{Nilai Profitability Ratio}

Nilai rasio profitabilitas merupakan rasio untuk menilai kemampuan perusahaan dalam mencari keuntungan (Kasmir, 2014). Secara keseluruhan, nilai profitability ratio dari seluruh alat tangkap yang diteliti masing-masing setiap alat tangkap di atas $1(\mathrm{Net} \mathrm{B} / \mathrm{C}>1)$. Nilai ini menunjukkan angka yang bervariasi, yaitu mulai 1,21 hingga 8,05. Alat tangkap yang memiliki nilai terendah adalah pukat cincin, sedangkan nilai yang tertinggi dicapai oleh alat tangkap bubu kemudian diikuti oleh pancing tonda $(5,13)$ dan pancing rawai $(4,91)$ (Gambar $3)$.

\section{Net Present Value (NPV)}

Net present value adalah selisih antara present value aliran kas bersih atau sering disebut juga dengan procceed dengan present value investasi (Sartono, 2010). Net present value dari seluruh alat tangkap yang diteliti, diperoleh nilai pada masing-masing setiap alat tangkap di atas 0 (nol) (Net present value >0). Nilai ini menunjukkan angka yang bervariasi, yaitu mulai Rp.2.535.720 hingga Rp.100.784.670. Alat tangkap yang memiliki nilai terendah adalah jaring dasar, sedangkan nilai yang tertinggi dicapai oleh alat tangkap bagan kemudian diikuti oleh pancing tonda (Rp.78.716.190) dan pancing tangan (Rp.17.193.110) (Gambar 4).

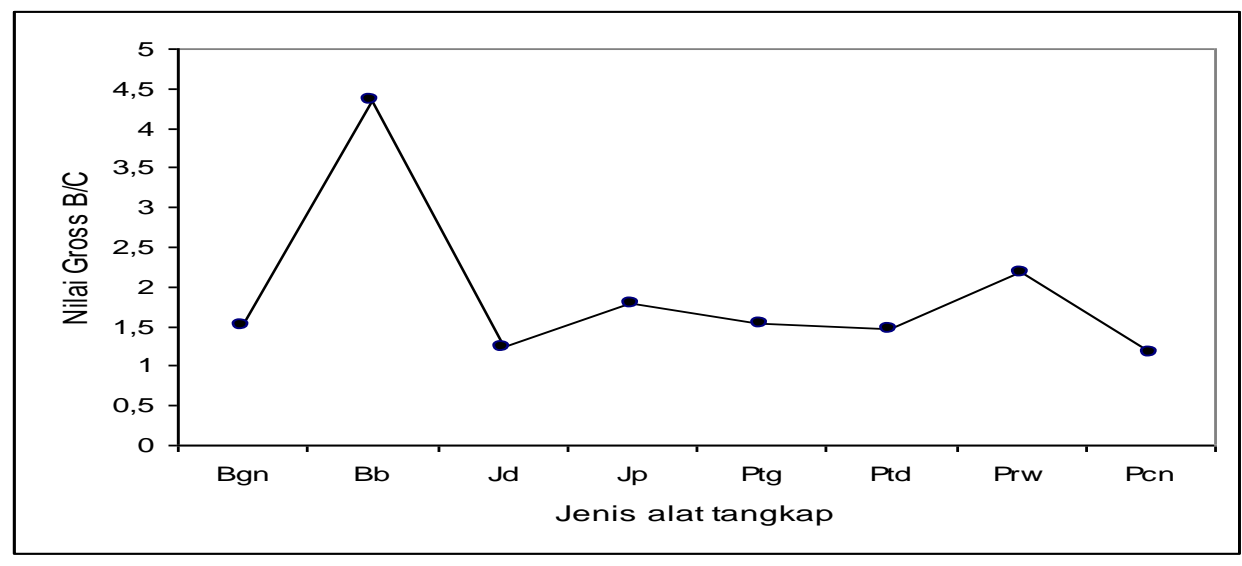

Gambar 2. Grafik nilai Gross B/C 


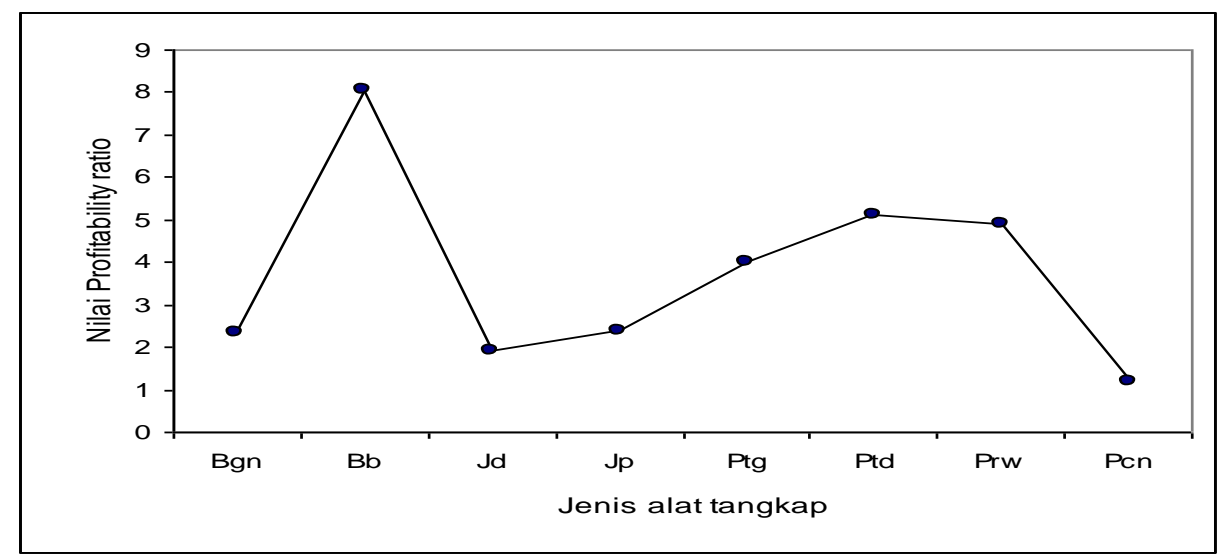

Gambar 3. Grafik nilai Profitability Ratio

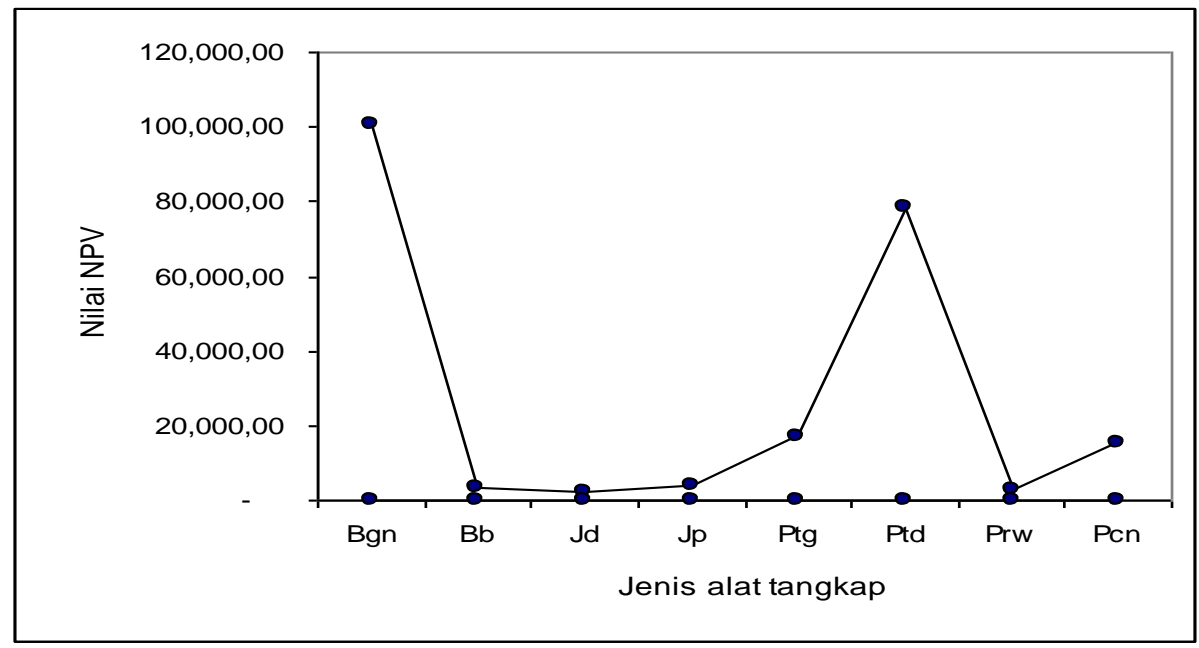

Gambar 4. Grafik Net Present Value

\section{Nilai Rating dan Skor}

Berdasarkan hasil analisis financial tentang criteria investasi suatu usaha (Gross B/C, Net B/C, Profitability ratio dan Net present value), analisa dilanjutkan dnegan metode skoring untuk mengetahui usaha yang menjadi pilihan. Nilai-nilai peringkat, rating dan skor dari setiap alat tangkap menunjukkan angka-angka yang bervariasi (Tabel 9). Nilai rating yang tertinggi dari Gross B/C diwakili oleh alat tangkap bubu (4), kemudian diikuti oleh alat tangkap jaring permukaan dan pancing rawai. Nilai rating $N e t \mathrm{~B} / \mathrm{C}$ nilai tertinggi diwakili oleh alat tangkap bubu dan pancing rawai (4) kemudian disusul oleh alat tangkap pancing tangan dan tonda. Nilai rating profitability ratio tertinggi diwakili oleh alat tangkap bubu (4), diikuti oleh alat tangkap pancing tonda dan pancing rawai (3) serta pancing tangan (2). Nilai rating dari net present value tertinggi dimiliki oleh alat tangkap bagan
(4) kemudian diikuti oleh alat tangkap pancing tonda (3). Nilai total skor dari keseluruhan alat tangkap menunjukkan angka berkisar antara 1,00 hingga 3,55 . Alat tangkap yang memiliki nilai skor tertinggi adalah bubu kemudian diikuti oleh alat tangkap pancing rawai $(2,70)$ dan pancing tonda $(2,10)$ (Tabel 10).

Tabel 9. Nilai peringkat rating setiap alat tangkap

\begin{tabular}{lcccc}
\hline \multicolumn{1}{c}{ Jenis alat } & $\begin{array}{c}\text { Gross } \\
\text { B/C }\end{array}$ & $\begin{array}{c}\text { Net } \\
\text { B/C }\end{array}$ & $\begin{array}{c}\text { Profit. } \\
\text { Ratio }\end{array}$ & $\begin{array}{c}\text { NP. } \\
\text { Value }\end{array}$ \\
\hline 1. Bagan & 1 & 1 & 1 & 4 \\
2. Bubu & 4 & 4 & 4 & 1 \\
3. Jaring dasar & 1 & 1 & 1 & 1 \\
4. Jaring permukaan & 2 & 1 & 1 & 1 \\
5. Pancing tangan & 1 & 2 & 2 & 1 \\
6. Pancing tonda & 1 & 2 & 3 & 3 \\
7. Pancing rawai & 2 & 4 & 3 & 1 \\
8. Pukat cincin & 1 & 1 & 1 & 1 \\
\hline Sumber : Data yang diolah & & & &
\end{tabular}


DOI: https://doi.org/10.30598/TRITONvol17issue1page46-56

Tabel 10. Nilai skor total setiap alat tangkap

\begin{tabular}{lccccc}
\hline \multicolumn{1}{c}{ Jenis Usaha /Alat } & $\begin{array}{c}\text { Gross } \\
B / C\end{array}$ & $\begin{array}{c}\text { Net } \\
B / C\end{array}$ & $\begin{array}{c}\text { Profit. } \\
\text { Ratio }\end{array}$ & $\begin{array}{c}\text { NP. } \\
\text { Value }\end{array}$ & $\begin{array}{c}\text { Jumlah } \\
\text { skor }\end{array}$ \\
\hline 1. Bagan & 0,30 & 0,30 & 0,25 & 0,60 & $\mathbf{1 , 4 5}$ \\
2. Bubu & 1,20 & 1,20 & 1,0 & 0,15 & $\mathbf{3 , 5 5}$ \\
3. Jaring dasar & 0,30 & 0,30 & 0,25 & 0,15 & $\mathbf{1 , 0 0}$ \\
4. Jaring permukaan & 0,60 & 0,30 & 0,25 & 0,15 & $\mathbf{1 , 3 0}$ \\
5. Pancing tangan & 0,30 & 0,60 & 0,50 & 0,15 & $\mathbf{1 , 5 5}$ \\
6. Pancing tonda & 0,30 & 0,60 & 0,75 & 0,45 & $\mathbf{2 , 1 0}$ \\
7. Pancing rawai & 0,60 & 1,20 & 0,75 & 0,15 & $\mathbf{2 , 7 0}$ \\
8. Pukat cincin & 0,30 & 0,30 & 0,25 & 0,15 & $\mathbf{1 , 0 0}$ \\
\hline Sumber: Data yang diolah & & & & &
\end{tabular}

Usaha perikanan tangkap yang dilakukan oleh para nelayan di Teluk Ambon Luar (TAL) berdasarkan perhitungan kriteria investasi (Gross B/C, Net B/C, Profitability ratio dan Net Present Value) secara umum dikatakan menguntungkan dan layak. Usaha perikanan tangkap yang menguntungkan dan terbaik pertama di wilayah TAL adalah dari jenis usaha perikanan tangkap yang menggunakan bubu, karena alat tangkap ini berdasarkan perhitungan kriteria investasi memperoleh nilai skor tertinggi yaitu 3,55 , pancing rawai memperoleh nilai skor 2,70, pancing tonda memperoleh nilai skor 2,10. Kemudian diikuti dengan alat tangkap yang lain secara berturut-turut yaitu; pancing tangan, bagan, jaring permukaan, pukat cincin dan jaring dasar. Masyarakat nelayan TAL belum sepenuhnya memanfaatkan wilayah perairan dengan kelimpahan stok sumberdaya ikan sebagai sumber pendapatan untuk meningkatkan pendapatan serta kesejahteraan. Hal ini terbukti dengan tingkat pemanfaatan sumberdaya ikan, baik ikan pelagis kecil maupun ikan dimersal relatif masih rendah yaitu masing-masing sekitar $47 \%$ dan $48 \%$.

\section{KESIMPULAN}

Usaha perikanan tangkap yang dilakukan oleh para nelayan di Teluk Ambon Luar (TAL) berdasarkan perhitungan kriteria investasi dikatakan menguntungkan dan layak. Usaha perikanan tangkap yang menguntungkan dan terbaik yaitu jenis usaha perikanan tangkap yang menggunakan alat tangkap bubu. Tingkat pemanfaatan sumberdaya ikan pelagis kecil sekitar $47 \%$ dan pelagis besar sekitar $48 \%$.

\section{DAFTAR PUSATAKA}

Dinas Kelautan dan Perikanan Provinsi Maluku. 2003. Penyusunan Data Spasial Sumberdaya Perikanan dan Kelautan Propinsi Maluku; Ringkasan Eksekutif. Pelaksana Lembaga Penelitian Universitas Pattimura, Ambon.

Dinas Kelautan dan Perikanan Kota Ambon. 2008. Profil Sumberdaya Kelautan dan Perikanan. Data dan Analisis Sumberdaya Kelautan dan Perikanan.

Drija \& C. Abdurahman. 2019. Studi Penangkapan Ikan Dengan Bagan Tancap di Perairan Bondet Kabupaten Cirebon, Jawa Tengah. Barakuda 1(1): 27-32.

Farhaby, A.M. 2019. Analisis Usaha Perikanan Tangkap Kapal Bagan di Pulau Celagen Kecamatan Kepulauan Pongok Kabupaten Bangka Selatan. Aquatic Science Jurnal Ilmu Perairan 1(1): 33-37.

Gittinger, J.P. 2008. Analisa Ekonomi ProyekProyek Pertanian. Penerbit UI Press. Jakarta.

Gray, C., L.L. Sabur, P. Simanjuntak, P.F.L. Maspaitella. Pengantar Evaluasi Proyek. PT Gramedia. Jakarta. 270 hal.

Ibrahim, H.M.Y. 2003. Studi Kelayakan Bisnis. Jakarta: PT Rineka Cipta.

Indrabudi, T. \& R. Alik. 2017. Status Kondisi Terumbu Karang di Teluk Ambon. Widyariset 3(1): 81-94.

Kadariah. 1999. Evaluasi Proyek Analisis Ekonomi. Jakarta. Lembaga Penelitian Fakultas Ekonomi UI.

Kasmir. 2014. Analisis Laporan Keuangan, Edisi Pertama, Cetakan Ketujuh. Jakarta: PT. Rajagrafindo Persada.

Kusdiantoro, A. Fachrudin, S.H. Wisudo, B. Juanda. Perikanan Tangkap di Indonesia: Potret Tantangan Keberlanjutannya. Jurnal Sosek. KP 14(2): 145-162.

Noija, D., S. Martasuganda, B. Murdiyanto, A.A. Taurusman. 2014. Potensi dan Tingkat Pemanfaatan Sumberdaya Ikan Demersal di Perairan Pulau Ambon Provinsi Maluku. Jurnal Teknologi Perikanan dan Kelautan 5(1): 55-64.

Patawari, A.M.Y. 2018. Pendapatan Pancing Ulur (Hand Line) di Desa Bongo, Kecamatan Batudaa Pantai, Kabupaten Gorontalo. Jurnal Perbal 6(1): 1-14. 
Purwasih, J.D., B. A. Wibowo, I. Triarso. 2016. Analisis Perbandingan Pendapatan Nelayan Pukat Cincin (Purse Seine) dan Pancing Tonda (Troll Line) di PPP Tamperan Pacitan, Jawa Timur. Journal of Fisheries Resources Utilization Management and Technology 5(1): 37-46.

Rahabeat, J., K. O. Londah, A. Ch. Nanlohy, E. Waileruny. 2019. Analisis Finansial Usaha Perikanan Pukat Cincin di Dusun Seri, Kota Ambon. Prosiding Seminar Nasional Kelautan dan Perikanan. Fakultas Perikanan dan Ilmu Kelautan Universitas Pattimura. ISBN 978-602-5943-27-0.

Rizal A, Iskandar, Herawati H, Dewanti LP. 2018. Potret dan Review: Strategi Pembangunan Perikanan dan Kelautan. Unpad Press. Bandung.

Rizky, M.F., Z. Anna, A. Rizal, A.A.H. Suryana. 2018. Sosial Eonomi dan Lingkungan Perikanan Bubu di Desa Karangsong Kabupaten Indramayu, Jawa Barat. Jurnal Kebijakan Sosek KP 8(2): 63-75.

Sanger CLM, Jusuf A., Andaki JA. 2019. Analisis Orientasi Kewirausahaan Nelayan Tangkap Skala Kecil dengan Alat Tangkap "JUBI" di
Kelurahan Batulubang Kecamatan Lembeh Selatan Kota Bitung. Akulturasi: Jurnal Ilmiah Agrobisnis Perikanan 7 (1): 10951101.

Shadiqin, I., R. Yusfiandayani, M. Imron. 2018. Produktivitas Alat Tangkap Pancing Ulur (Hand Line) pada Rumpon Portable di Perairan Kabupaten Aceh Utara. Jurnal Teknologi Perikanan dan Kelautan 9(2): 105113.

Syarif, S., S. Nursinar, Syamsuddin. 2016. Analisis Kelayakan Usaha Jaring Insang Dasar di Desa Pohuwato Timur. Nike: Jurnal Ilmiah Perikanan dan Kelautan 4(4): 120-126.

Sartono, A. 2010. Manajemen Keuangan Teori dan Aplikasi. Edisi 4. Yogjakarta: BPFE

Tamarol, J. \& C. I. Sarapil. 2017. Analisis Aspek Teknis dan Aspek Ekonomis Pukat Cincin (Mini Purse Seine) yang Dioperasikan di Rumpon. Jurnal Ilmiah Tindalung 3(1): 1522.

Triarso, I. 2012. Potensi dan Peluang Pengembangan Usaha Perikanan Tangkap di Pantura Jawa Tengah. Jurnal Saintek Perikanan 8(1): 6573. 